ХІРУРГІЧНА СТОМАТОЛОГІЯ

удК 616.314.8-007.13-089.87]-06-037-084:004.94

DOI 10.11603/2311-9624.2016.4.7235

(С). В. Кияк

Львівський національний медичний університет імені Данила Галицького

\title{
До проблеми прогнозування складності та травматичності атипового видалення нижніх третіх молярів на підставі вивчення рентгенологічних критеріїв їх ретенції
}

Резюме. Ретенція зуба - це аномалія розвитку, спричинена перешкодою на шляху прорізування або ектопічним розміщенням певного зуба. Перед проведенням екстракції «зубів мудрості» необхідним $€$ ретельне рентгенологічне обстеження. На рентгенологічній оцінці грунтуються і більшість класифікацій ретенції та алгоритмів лікувальної тактики. 3 історії відомо про чисельні спроби створення моделі визначення тяжкості видалення нижніх ретенованих третіх молярів (MacGregor, 1979, M. Diniz-Freitas, 2007, H. Yuasa et al., 2002, G. L. Howe, 1971, A. M. Nieves et al., 2009 та інші). Метою роботи було удосконалення діагностичного підходу та планування атипового видалення нижніх ретенованих третіх молярів шляхом урахування комплексу рентгенологічних критеріїв. Завдання роботи полягали в оцінці складності, травматичності операції атипового видалення нижніх третіх молярів та здійсненні прогнозу можливих ускладнень на підставі рентгенологічних критеріїв ретенції. Синхронізація рентгенологічних та інших критеріїв ретенції нижніх третіх молярів із метою прогнозування виникнення ймовірних ускладнень, травматичності та тяжкості їх атипового видалення поліпшить якість операційного процесу та полегшить післяопераційний стан пацієнта. Створення комп’ютерної програми із включенням вказаних критеріїв спростить роботу стоматологів-хірургів, а також слугуватиме засобом візуалізації навчального процесу студентів та лікарів-інтернів.

Ключові слова: ретеновані нижні треті моляри; рентгенологічні критерії; складність атипового видалення; травматичність атипового видалення.

\section{С. В. Кияк}

Львовский национальный медицинский университет имени Данила Галицкого

\section{К проблеме прогнозирования сложности и травматичности атипичного удаления нижних третьих моляров на основании изучения рентгенологических критериев их ретенции}

Резюме. Ретенция зуба - это аномалия развития, вызванная препятствием на пути прорезывания или эктопическим размещением определенного зуба. Перед проведением экстракции «зубов мудрости» необходимо тщательное рентгенологическое обследование. На рентгенологической оценке основываются и большинство классификаций ретенции и алгоритмов лечебной тактики. Было осуществлено число попыток в создании модели определения тяжести удаления нижних ретенированных третьих моляров (MacGregor, 1979, M. Diniz-Freitas, 2007, H. Yuasa et al., 2002, G. L. Howe, 1971, A. M. Nieves et al., 2009 та інші). Целью работы было совершенствование диагностического подхода и планирования атипичного удаления нижних ретенированных третьих моляров путем учета комплекса рентгенологических критериев. Задания работы заключались в сложности, травматичности операции атипичного удаления нижних третьих моляров и осуществлении прогноза возможных осложнений на основании рентгенологических критериев ретенции. Синхронизация рентгенологических и других критериев ретенции нижних третьих моляров с целью прогнозирования возникновения возможных осложнений, травматичности и тяжести их атипичного удаления улучшит качество операционного процесса и облегчит послеоперационное состояние пациента. Создание компьютерной программы с включением указанных критериев упростит работу стоматологов-хирургов, а также будет служить средством визуализации учебного процесса студентов и врачей-интернов.

Ключевые слова: ретенированные нижние третьи моляры; рентгенологические критерии; сложность атипичного удаления; травматичность атипичного удаления. 


\author{
S. V. Kyyak \\ Danylo Halytskyi Lviv National Medical University
}

\title{
Prognosis of complexity and level of trauma of lower third molars atypical removal on the basis of radiologic criteria of their retention
}

\begin{abstract}
Summary. Tooth impaction is malformation which occurred because of obstruction on the way of its eruption or ectopic placing of the tooth. Thorough radiologic assessment is required before "wisdom tooth" extraction. Most of impactions classifications and treatment algorithms are built on the radiologic assessment. There were quite a few attempts to create a model which determine complexity of lower third molars removal (MacGregor, 1979, M. Diniz-Freitas, 2007, H. Yuasa et al., 2002, G. L. Howe, 1971, A. M. Nieves et al., 2009 etc.). The aim of the work was the improvement of diagnostic approach and planning of atypical removal of impacted lower third molars considering complex of radiologic criterions. Synchronization of radiological and other criterions of lower third molar impaction with the aim of prognosis of complications, level of trauma and difficulty of their atypical removal will improve quality of surgical process and relieve postoperative period of patients. Creation of computer program including these criterions will simplify the work of dental surgeons and will serve as an effective visualization of study process of students and interns.
\end{abstract}

Key words: lower third molars impaction; radiologic criterias; complexity of atypical removal; trauma from atypical removal.

Вступ. Ретенція зуба - це аномалія розвитку, спричинена перешкодою на шляху прорізування або ектопічним розміщенням певного зуба [11], який не встигає прорізатися в межах очікуваного часу [5]. Найчастіше ретенція спостерігається у третіх молярах, тому що вони прорізуються останніми [5]. Перед проведенням екстракції «зубів мудрості» необхідним $€$ ретельне рентгенологічне обстеження.

Власне на рентгенологічній оцінці грунтуються і більшість класифікацій ретенції та алгоритмів лікувальної тактики. Однією із найпоширеніших $€$ класифікація, яка полягає у визначенні нахилу довгої осі ретенованого третього моляра по відношенню до довгої осі сусіднього другого моляра, яка дає початкову корисну інформацію стосовно тяжкості видалення. Ангуляції бувають: мезіальні, горизонтальні, вертикальні, дистальні $[5,11,14]$. Існує також класифікація орального чи щічного нахилу [2].

Відомою класифікацією, яка грунтується на відношенні ретенованого зуба до переднього краю гілки нижньої щелепи є класифікація G. J. Pell та G. T. Gregory [13], у якій виокремлюють 3 підкласи. Якщо мезіодистальний діаметр коронки знаходиться попереду від переднього краю гілки, то це - клас 1; якщо 1/2 коронки вкрита гілкою, то це - 2 клас, а повністю вкрита гілкою це - 3 клас. Наступним критерієм, який враховує вказана класифікація, є відношення ретенованого зуба до оклюзійної площини і позначається класами А, В, С.
При класі А оклюзійна площина ретенованого нижнього «зуба мудрості» $€$ на рівні або близько рівня оклюзійної площини сусіднього другого моляра. При класі В оклюзійна площина ретенованого зуба - між оклюзійною площиною та цервікальною лінією другого моляра, а при класі С - під цією лінією [6].

Ще одним фактором, який впливає на ступінь тяжкості видалення «зуба мудрості» $€$ морфологія кореня. Перш за все береться до уваги довжина кореня. Оптимальний час для видалення ретенованого «зуба мудрості» $€$ період, коли корінь сформований від $1 / 3$ до 2/3, а його верхівки є тупими [5]. Наступними важливими факторами для оцінки тяжкості видалення є: наявність кількох чи одного конічного кореня; ступінь його викривлення; співвідношення мезіодистальної ширини коренів до ширини в ділянці цервікальної лінії; ширина періодонтальної зв'язки [3, 5, 11].

Також важливу роль у видаленні відіграють розмір фолікулярного мішечка навколо ретенованого зуба, щільність навколишньої кістки, контакт із нижнім другим моляром, відношення до нижнього альвеолярного нерва, вид тканин, що покривають нижній ретенований третій моляр (м’які тканини, частково кістка, лише кістка) [5].

Що стосується комп’ютерної томографії, то цей вид діагностики дає інформацію стосовно розташування нижнього «зуба мудрості» щодо нижнього щелепного каналу у всіх площи- 
нах, а також точнішу інформацію щодо морфології кореня досліджуваного зуба [7, 17] рідше, при тяжкій формі дистопії уточнює розташування нижнього «зуба мудрості» в куті, гілці нижньої щелепи. Комп’ютерна томографія застосовується також для діагностики післяопераційних ускладнень: зміщення нижнього третього моляра в крилощелепний простір [16], осифікуючий міозит [9] тощо.

Було здійснено чимало спроб у визначенні моделі цієї оцінки. Першу спробу опублікував MacGregor [15] у 1979 році, який заснував багатовимірну модель WHARFE, що базується на панорамній рентгенографії і включає класифікацію Вінтера (класифікація ангуляцій третього моляра), висоту нижньої щелепи в міліметрах, ангуляцію другого моляра, вигнутість кореня третього моляра та стадію його розвитку, стан фолікула та місце для видалення. Кожен з пунктів має свою оцінку складності видалення від «-3» до «4», за сумою яких визначається тяжкість операційного процесу [8]. M. Diniz-Freitas et al. [12] вважають, що оцінка тяжкості атипового видалення нижнього третього моляра повинна враховувати й інші фактори, окрім анатомічного розташування зуба. У своїй роботі науковці заявили, що шкала «Pederson", яка включає лише такі характеристики, як ангуляція нижнього третього моляра, глибина розташування та відношення до нижньощелепної гілки, не дає достовірної інформації як важко буде видалятися нижній третій моляр. H. Yausa et al. [18] вважають, що складність атипового видалення залежить від глибини ретенції (клас С) стосовно оклюзійної площини, наявності місця між сусіднім другим моляром та гілкою нижньої щелепи (клас 3), ширини коренів (корені повністю сформовані, об’єднані, ширші у середній третині від шийки зуба) або комбінації усіх вказаних факторів. Науковці вважають, що даний індекс є достовірнішим від класичного індексу "Pederson". Орієнтуючись на так звані WARлінії Вінтера, G. L. Howe [6] повідомляє, що 3 кожним подовженням «червоної лінії» на 1 мм трьохкратно ускладнюється операція атипового видалення ретенованого нижнього третього моляра.

Матеріали і методи. Залежно від виду ретенції та їі характеристик прогнозуються характерні ускладнення. Так, А. M. Nieves et al. [10] наголошують, що вертикально розташовані треті моляри у позиції IIA та IIB за класифікацією «Pell and Gregory» із частковою м'якотканинною та кістковою ретенцією $€$ найбільш вразливі до небажаних результатів.

Метою роботи було удосконалення діагностичного підходу та планування атипового видалення нижніх ретенованих третіх молярів шляхом урахування комплексу рентгенологічних критеріїв.

Завдання роботи полягали в оцінці складності, травматичності операції атипового видалення нижніх третіх молярів та здійсненні прогнозу можливих ускладнень на підставі рентгенологічних критеріїв ретенції.

Результати досліджень та їх обговорення. Враховуючи вищенаведену інформацію, а також власний багаторічний досвід, ми систематизували усі вагомі рентгенологічні критерії, вказали, який рівень складності операції атипового видалення очікується за їх наявності, а також рівень травми та можливі ускладнення (табл. 1-3).

Зібравши критерії операції атипового видалення нижнього ретенованого третього моляра, ми оцінили їх за складністю та рівнем травми (табл. 4).

таблиця 1. Рентгенологічні характеристики запальних процесів

\begin{tabular}{|c|c|c|c|c|}
\hline \multirow{2}{*}{ Критерій } & \multirow{2}{*}{ Значення критеріїв } & \multicolumn{2}{|c|}{$\begin{array}{c}\text { Характеристика } \\
\text { операції }\end{array}$} & \multirow{2}{*}{ Ускладнення } \\
\hline & & $\begin{array}{l}\text { склад- } \\
\text { ність }\end{array}$ & $\begin{array}{l}\text { рівень } \\
\text { травми }\end{array}$ & \\
\hline Періодонтит & $\begin{array}{l}\text { Наявний } \\
\text { Відсутній }\end{array}$ & - & - & $\begin{array}{l}\text { Наявний - схильність до більшо- } \\
\text { го післяопераційного запаленн, } \\
\text { до значної інтенсивності після- } \\
\text { операційного болю }\end{array}$ \\
\hline Резорбція кістки & $\begin{array}{l}\text { Наявна } \\
\text { Відсутня }\end{array}$ & 1 & - & $\begin{array}{l}\text { Наявна - схильність до більшого } \\
\text { післяопераційного запалення, до } \\
\text { значної інтенсивності післяопе- } \\
\text { раційного болю }\end{array}$ \\
\hline
\end{tabular}


таблиия 2. Рентгенологічні характеристики досліджуваного ретенованого нижнього третього моляра та сусідніх до нього анатомічних структур

\begin{tabular}{|c|c|c|c|c|}
\hline \multirow[b]{2}{*}{ Критерій } & \multirow[b]{2}{*}{ Значення критерію } & \multicolumn{2}{|c|}{ Характеристика операції } & \multirow[b]{2}{*}{ Ускладнення } \\
\hline & & $\begin{array}{l}\text { склад- } \\
\text { ність }\end{array}$ & рівень травми & \\
\hline $\begin{array}{l}\text { Величина коронки } \\
\text { відносно сусідньо- } \\
\text { го другого моляра }\end{array}$ & $\begin{array}{l}\text { Велика } \\
\text { Невелика }\end{array}$ & $\begin{array}{l}2 \\
1\end{array}$ & $\begin{array}{l}\text { Середньої тяжкості/ } \\
\text { сильна } \\
\text { Мінімальна }\end{array}$ & $\begin{array}{l}\text { Велика - більша ймовір- } \\
\text { ність перелому нижньої } \\
\text { щелепи (при класах «В», «С») }\end{array}$ \\
\hline $\begin{array}{l}\text { Стадія розвитку } \\
\text { кореня }\end{array}$ & \begin{tabular}{|l|} 
Закінчений ріст на 1/3 \\
Закінчений ріст на 1/3-2/3 \\
Закінчений ріст на > 2/3 \\
Закінчений ріст
\end{tabular} & $\begin{array}{l}2 \\
1 \\
3 \\
3\end{array}$ & $\begin{array}{l}\text { Мінімальна } \\
\text { Середньої тяжкості } \\
\text { Середньої тяжкості } \\
\text { Сильна }\end{array}$ & $\begin{array}{l}\text { Закінчений ріст - ризик від- } \\
\text { лому кінчика кореня }\end{array}$ \\
\hline $\begin{array}{l}\text { Анатомія кореня } \\
\text { третього моляра }\end{array}$ & $\begin{array}{l}\text { Булавоподібний } \\
\text { Конусоподібний }\end{array}$ & $\begin{array}{l}2 \\
1\end{array}$ & $\begin{array}{l}\text { Сильна } \\
\text { Мінімальна }\end{array}$ & $\begin{array}{l}\text { Булавоподібний - більша } \\
\text { ймовірність перелому ниж- } \\
\text { ньої щелепи }\end{array}$ \\
\hline Кількість коренів & $\begin{array}{l}1 \\
\geq 2 \\
\text { Відсутні }\end{array}$ & $\begin{array}{l}1 \\
2 \\
3\end{array}$ & $\begin{array}{l}\text { Мінімальна } \\
\text { Сильна } \\
\text { Середньої тяжкості }\end{array}$ & $\begin{array}{l}\geq 2 \text { - більша ймовірність } \\
\text { перелому нижньої щелепи } \\
\text { (при класі «В», «С») }\end{array}$ \\
\hline Вигин кореня & $\begin{array}{l}\text { 1.Не вигнутий }\left(<10^{\circ}\right) \text {. } \\
\text { 2. Вигнутий, але сприят- } \\
\text { ливий для видалення. } \\
\text { 3. Вигнутий }\left(>10^{\circ}\right), \text { не } \\
\text { сприятливий для вида- } \\
\text { лення: } \\
\text { - закінчений ріст на } 1 / 3 \\
\text { довжини; } \\
\text { - закінчений ріст на 1/3-2/3; } \\
\text { - закінчений ріст > } 2 / 3 \\
\text { довжини }\end{array}$ & $\begin{array}{l}2 \\
1 \\
3\end{array}$ & $\begin{array}{l}\text { Мінімальна } \\
\text { Середньої тяжкості } \\
\text { Сильна } \\
\text { Середньої тяжкості } \\
\text { Мінімальна } \\
\text { Сильна }\end{array}$ & $\begin{array}{l}\text { Сприятливо вигнутий - } ~ \\
\text { ризик відлому кінчика ко- } \\
\text { реня. } \\
\text { Несприятливо вигнутий - } \\
\text { високий ризик відлому кін- } \\
\text { чика кореня }\end{array}$ \\
\hline $\begin{array}{l}\text { Періодонтальна } \\
\text { щілина }\end{array}$ & $\begin{array}{l}\text { Рентгенонеконтрастна } \\
\text { Змішана } \\
\text { Рентгеноконтрастна }\end{array}$ & $\begin{array}{l}3 \\
2 \\
1\end{array}$ & $\begin{array}{l}\text { Сильна } \\
\text { Середньої тяжкості } \\
\text { Мінімальна } \\
\end{array}$ & $\begin{array}{l}\text { Рентгенонеконтрастна - } \\
\text { є ймовірність анкілозу зуба } \\
\text { мудрості з кісткою }\end{array}$ \\
\hline $\begin{array}{l}\text { Відношення } \\
\text { кореня до нижньо- } \\
\text { щелепного каналу }\end{array}$ & $\begin{array}{l}\text { Немає відношення (від- } \\
\text { стань > } 2 \text { мм) } \\
\text { Прилеглий } \\
\text { (відстань = } 2 \text { мм) } \\
€ \text { відношення (відстань } \\
\text { < 2 мм) }\end{array}$ & $\begin{array}{l}3 \\
1 \\
2\end{array}$ & $\begin{array}{l}\text { Сильна } \\
\text { Мінімальна } \\
\text { Середньої тяжкості }\end{array}$ & $\begin{array}{l}\text { Прилеглий - є відношення } \\
\text { - ризик виникнення парес- } \\
\text { тезії після операції. Реко- } \\
\text { мендовано перед операцією } \\
\text { комп’ютерну томографію }\end{array}$ \\
\hline $\begin{array}{l}\text { Фолікул навколо } \\
\text { третього моляра }\end{array}$ & $\begin{array}{l}\text { Нормальний } \\
\text { Незначно збільшений } \\
\text { Збільшений }\end{array}$ & $\begin{array}{l}1 \\
2 \\
3\end{array}$ & $\begin{array}{l}\text { Мінімальна } \\
\text { Середньої тяжкості } \\
\text { Сильна }\end{array}$ & \\
\hline
\end{tabular}

таблиця 3. Рентгенологічні характеристики ретенції нижнього третього моляра

\begin{tabular}{|c|c|c|c|c|}
\hline \multirow[b]{2}{*}{ Критерій } & \multirow{2}{*}{$\begin{array}{l}\text { Значення } \\
\text { критеріїв }\end{array}$} & \multicolumn{2}{|c|}{ Характеристика операції } & \multirow[b]{2}{*}{ Ускладнення } \\
\hline & & $\begin{array}{c}\text { склад- } \\
\text { ність }\end{array}$ & рівень травми & \\
\hline 1 & 2 & 3 & 4 & 5 \\
\hline $\begin{array}{l}\text { Глибина } \\
\text { ретенцї̈ }\end{array}$ & $\begin{array}{l}\text { «А - Висока } \\
\text { «В»- середня } \\
\text { «С»- глибока }\end{array}$ & $\begin{array}{l}1 \\
2 \\
3\end{array}$ & $\begin{array}{l}\text { Мінімальна } \\
\text { Середньої } \\
\text { тяжкості } \\
\text { Сильна }\end{array}$ & $\begin{array}{l}\text { Типи «В», «С»- прогнозується більший після- } \\
\text { операційний біль, набряк, тризм, є імовірність } \\
\text { перелому нижньої щелепи. Тип «С» - є імовір- } \\
\text { ність ушкодження нижньощелепного нерва, } \\
\text { ризик відлому кінчика кореня }\end{array}$ \\
\hline $\begin{array}{l}\text { Розташування } \\
\text { відносно гілки } \\
\text { нижньої щелепи }\end{array}$ & $\begin{array}{l}\text { Клас } 1 \\
\text { Клас } 2 \\
\text { Клас } 3\end{array}$ & $\begin{array}{l}1 \\
2 \\
3\end{array}$ & $\begin{array}{l}\text { Мінімальна } \\
\text { Середньої тяжкості } \\
\text { Сильна }\end{array}$ & $\begin{array}{l}\text { Клас } 2 / 3 \text { - прогнозується більший післяопера- } \\
\text { ційний біль, набряк, тризм, є імовірність пере- } \\
\text { лому нижньої щелепи }\end{array}$ \\
\hline
\end{tabular}




\section{Хірургічна стоматологія}

Продовження табл. 3

\begin{tabular}{|c|c|c|c|c|}
\hline 1 & 2 & 3 & 4 & 5 \\
\hline Вид ангуляції & $\begin{array}{l}\text { Мезіальна } \\
\text { Горизонтальна } \\
\text { Вертикальна } \\
\text { Дистальна }\end{array}$ & $\begin{array}{l}1 \\
2 \\
3 \\
4\end{array}$ & $\begin{array}{l}\text { Мінімальна } \\
\text { Середньої тяжкості } \\
\text { Сильна } \\
\text { Сильна }\end{array}$ & $\begin{array}{l}\text { Дистальна - подовження часу } \\
\text { операції, що ускладнює після- } \\
\text { операційний період. Мезіальна } \\
\text { - найчастіше спричиняє внут- } \\
\text { рішньоопераційні ускладнення }\end{array}$ \\
\hline $\begin{array}{l}\text { Ангуляція другого } \\
\text { моляра }\end{array}$ & $\begin{array}{l}1-50^{\circ} \\
60-69^{\circ} \\
70-79^{\circ} \\
80-89^{\circ} \\
90+^{\circ}\end{array}$ & $\begin{array}{l}1 \\
2 \\
3 \\
4 \\
5\end{array}$ & $\begin{array}{l}\text { Мінімальна } \\
\text { Середньої тяжкості } \\
\text { Сильна } \\
\text { Сильна } \\
\text { Сильна }\end{array}$ & \\
\hline $\begin{array}{l}\text { Контакт із } \\
\text { сусіднім другим } \\
\text { моляром }\end{array}$ & $\begin{array}{l}\text { Відсутній } \\
3 \text { коронкою } \\
\text { Коронкою } \\
\text { і коренем } \\
\text { Коренем }\end{array}$ & $\begin{array}{l}1 \\
2\end{array}$ & $\begin{array}{l}\text { Мінімальна } \\
\text { Середньої тяжкості } \\
\text { Сильна } \\
\text { Сильна }\end{array}$ & $\begin{array}{l}\text { Контакт із коронкою і коренем, } 3 \\
\text { коренем - несприятливий паро- } \\
\text { донтологічний прогноз } \\
\text { сусіднього другого моляра, є ризик } \\
\text { пошкодження другого моляра під } \\
\text { час видалення }\end{array}$ \\
\hline
\end{tabular}

таблищя 4. Оцінка критеріїв операції атипового видалення нижнього ретенованого третього моляра

\begin{tabular}{|c|c|c|c|}
\hline \multirow[b]{2}{*}{ Критерій } & \multirow[b]{2}{*}{ Характеристика критеріїв } & \multicolumn{2}{|c|}{ Характеристика операції } \\
\hline & & $\begin{array}{l}\text { склад- } \\
\text { ність* }\end{array}$ & рівень травми \\
\hline $\begin{array}{l}\text { Щічна кістка, } \\
\text { яку потрібно } \\
\text { препарувати } \\
\end{array}$ & $\begin{array}{l}\text { Верхня 1/3 кореня } \\
\text { Середня } 1 / 3 \text { кореня } \\
\text { Нижня } 1 / 3 \text { кореня } \\
\end{array}$ & $\begin{array}{l}2 \\
3\end{array}$ & $\begin{array}{l}\text { Мінімальна } \\
\text { Середньої тяжкості } \\
\text { Сильна } \\
\end{array}$ \\
\hline $\begin{array}{l}\text { Види } \\
\text { операційного } \\
\text { втручання }\end{array}$ & $\begin{array}{l}\text { 1. Щипцмии й елеваторами, без розтину слизово-окісного клаптя. } \\
\text { 2. Відшарування слизово-окісного клаптя та видалення щип- } \\
\text { цями та/або елеватором. } \\
\text { 3. Відшарування слизово-окісного клаптя, видалення кістки } \\
\text { зі щічного боку та видалення щипцями та/або елеватором. } \\
\text { 4. Відшарування слизово-окісного клаптя, видалення кістки } \\
\text { зі щічного та оклюзійного боку із секціонуванням зуба; вида- } \\
\text { лення щипцями та/або елеватором: } \\
\text { а) із секціонуванням коронки; } \\
\text { в) із секціонуванням кореня. }\end{array}$ & $\begin{array}{l}1 \\
2 \\
3 \\
4 \\
4 \\
5 \\
5\end{array}$ & $\begin{array}{l}\text { Дуже мінімальна } \\
\text { Мінімальна } \\
\text { Середньої тяжко- } \\
\text { сті } \\
\text { Сильна }\end{array}$ \\
\hline Час операції & $\begin{array}{l}\text { 1. Клас «1» та глибина «А», клас «2» та глибина «А», клас «1» } \\
\text { та глибина «В»- 15-25 хвилин (якщо оперує недосвідчений } \\
\text { хірург) та } \leq 15 \text { хвилин (якщо оперує досвідчений хірург). } \\
\text { 2. Клас «3» та глибина «А», клас «4» та глибина «А», Клас «1» } \\
\text { та глибина «С»- } 35 \text { хвилин (якщо оперує недосвідчений хі- } \\
\text { рург) та 16-30 хвилин (якщо оперує досвідчений хірург). } \\
\text { 3. Клас «3» та глибина «В», клас «4» та глибина «В», клас «3» } \\
\text { та глибина «С», клас «2» та глибина «С», клас «4» та глибина } \\
\text { «С - } 45 \text { хвилин (якщо оперує недосвідчений хірург) та } \geq 31 \\
\text { хвилини (якщо оперує досвідчений хірург) }\end{array}$ & $\begin{array}{c}1 \\
2 / 3 \\
4 / 5\end{array}$ & $\begin{array}{l}\text { Мінімальна } \\
\text { Середньої тяжко- } \\
\text { сті / сильна } \\
\text { Сильна }\end{array}$ \\
\hline $\begin{array}{l}\text { Необхідність } \\
\text { секціонувати } \\
\text { зуб }\end{array}$ & $\begin{array}{l}\text { Потрібно } \\
\text { Не потрібно }\end{array}$ & $\begin{array}{l}4 \\
1\end{array}$ & $\begin{array}{l}\text { Сильна } \\
\text { Мінімальна }\end{array}$ \\
\hline $\begin{array}{l}\text { Необхідність } \\
\text { препарувати } \\
\text { кістку з дис- } \\
\text { тального боку }\end{array}$ & $\begin{array}{l}\text { Потрібно } \\
\text { Не потрібно }\end{array}$ & $\begin{array}{l}3 \\
1\end{array}$ & $\begin{array}{l}\text { Сильна } \\
\text { Мінімальна }\end{array}$ \\
\hline
\end{tabular}

Примітка: * - складність хірургічного втручання:

1 - операційне втручання легке;

2 - середньої складності;

3 - складне;

4, 5 - дуже складне з маніпулятивними ускладненнями. 
Вказані критерії включили у створену нами комп’ютерну програму діагностики ретенції нижніх ретенованих третіх молярів та планування їх атипового видалення «X-ray analyzer», на яку отримано патент України на корисну модель [1].

Висновки. У медичній літературі пропонуються різні варіанти передопераційної діагностики нижніх ретенованих третіх молярів, гостро постають питання оцінки потенційних ризиків вказаної хірургічної маніпуляції та удосконалення власне операційних методик за допомогою сучасних методів діагностики.

Синхронізація рентгенологічних та інших критеріїв ретенції нижніх третіх молярів 3

\section{Список літератури}

1. Пат. №89563 U Україна, МПК А 61 С 3/00. Спосіб передопераційної оцінки ретенції атипового видалення нижнього третього моляра / Заявники та патентовласники: Я. Е. Варес, С. В. Кияк- № u 2013 13650; заявл. 25.11.2013; опубл. 25.04.2014, Бюл. № 8. 2. Archer W. H. Oral and Maxillofacial Surgery / W. H. Archer - 5th ed. - Philadelphia : WB Saunders, 1975. - Vol. 1. $-522 \mathrm{p}$.

3. Assessment of factors associated with surgical difficulty in impacted mandibular third molar extraction / O. M. Gbotolorun, G. T. Arotiba, A. L. Ladeinde // J. Oral Maxillofac. Surg. - 2007. - Vol. 65, № 10. - P. 1977-1983.

4. Carvalho R. W. Assessment of factors associated with surgical difficulty during removal of impacted lower third molars / R. W. Carvalho, B. C. Vasconcelos // J. Oral Maxillofac. Surg. - 2011. - Vol. 69, № 11. - P. 2714-2721.

5. Contemporary Oral and Maxolllofacial Surgery / edit. J. R. Hupp, E. Ellis, M. R. Tucker - 5th ed. - St. Luise : MOSBY Elsevier, 2008. - 250 p.

6. Howe G. L. Minor oral surgery / G. L. Howe - 2nd ed. Bristol: John Wright and Sons Publishers Ltd. - 1971. P. 89-115.

7. Inferior alveolar nerve injury and surgical difficulty prediction in third molar surgery: the role of dental panoramic tomography / W. Jerjes, M. El-Maaytah, B. Swinson [et al.] // J. Clin. Dent. - 2006. - Vol. 17, № 5. P. 122-130.

8. Longson M. Persistence in herpes simplex virus infections / M. Longson // Postgrad. Med. J. - 1978. Vol. 54, № 635. - P. 603-612.

9. Myositis ossificans circumscripta of the buccinator muscle: First report of a rare complication of mandibular third molar extraction / R. L. Wiggins, D. Thurber, K. Abramovitch [et al.] // J. Oral Maxillofac. Surg. - 2008. Vol. 66, № 9. - P. 1959-1963. метою прогнозування виникнення ймовірних ускладнень, травматичності та тяжкості їх атипового видалення поліпшить якість операційного процесу та полегшить післяопераційний стан пацієнта. Створення комп’ютерної програми із включенням вказаних критеріїв спростить роботу стоматологів-хірургів, а також слугуватиме ефективною візуалізацією навчального процесу студентів та лікарівінтернів. Враховуючи вищевказане, доцільні подальші дослідження з удосконалення методик операції атипового видалення на підставі вивчення їх складності, травматичності та потенційних ускладнень.

10. Nieves A. M. Evaluation of Intraexaminer and Interexaminer Agreement on Classifying Lower Third Molars According to the Systems of Pell and Gregory and of Winter / A. M. Nieves, B. A. Leonardo, G. E. Cosme // J. Oral Maxillofac. Surg. - 2008. - Vol. 66, № 5. - P. 893899.

11. Oral and Maxillofacial Surgery / edit. L. Andersson, K. E. Kahnberg, M. Pogrel - Chichester : Wiley- Blackwell, 2010. $-1273 \mathrm{p}$.

12. Pederson scale fails to predict how difficult it will be to extract lower third molars / M. Diniz-Freitas, L. LagoMendez, F. Gude-Sampedro // Brit. J. Oral Maxillofac. Surg. - 2007. - Vol. 45, № 1. - P. 23-26.

13. Pell G. J. Impacted mandibular third molars: classifications and modified technique for removal / G. J. Pell, G. T. Gregory // Dent. Digest. - 1933. - Vol. 39. P. 330-338.

14. Peterson's Principles Of Oral And Maxillofacial Surgery / edit. M. Miloro, G. E. Ghali, E. L. Peter - 2nd ed. - London : BC Decker Inc. Hamilton, 2004. - 1502 p. 15. Prediction of postoperative facial swelling, pain and trismus following third molar surgery based on preoperative variables / T. Santana-Santos, J. SouzaSantos, P. R. Martins-Filho [et al.] // Med. Oral Patol. Oral Cir. Bucal. - 2013. - Vol. 18, № 1. - P. 65-70.

16. Surgical management of accidentally displaced mandibular third molar into the pterygomandibular space: a case report / I. Y. Huang, C. M. Chen, S. W. Chang // J. Med. Sci. - 2007. - Vol. 23, № 7. - P. 370-374.

17. Susarla S. M. Preoperative computed tomography imaging in the management of impacted mandibular third molars / S. M. Susarla, T. B. Dodson // J. Oral Maxillofac. Surg. - 2007. - Vol. 65, № 1. - P. 83-88.

18. Yuasa $\mathrm{H}$. Classification of surgical difficulty in extracting third molars / H. Yuasa, T. Kawai, M. Sugiura // Brit. J. Oral Maxillofac. Surg. - 2002. - Vol. 40, № 1. P. 26-31. 